\title{
Üniversite Öğrencilerinin Çocukluk Çağı Olumsuz Yaşantıları ve Kendini Sansürleme İsteğinde Ego Durumlarının Aracılık Rolü
}

\author{
Childhood Negative Experiences of University Students and the Mediating Role of Ego \\ Situations in Willingness to Self-Censorship
}

\section{Onur Emre KAYABAŞI ${ }^{[1]}$ Ahmet SAPANCI ${ }^{[2]}$}

Bu çalışmada üniversite öğrencilerinin çocukluk çağı olumsuz yaşantıları ve kendini sansürleme isteğinde Transaksiyonel Analiz kuramı ego durumları modelindeki ebeveyn, yetişkin ve çocuk ego durumlarının aracılık etkisinin olup olmadığının incelenmesi amaçlanmıştır. Çalışma nicel araştırma yöntemlerinden ilişkisel tarama modeline uygun bir biçimde düzenlenmiştir. Bu kapsamda araştırmanın çalıșma grubunu farklı üniversitelerde ve fakültelerde lisans öğrenimini sürdüren 343 üniversite öğrencisi oluşturmaktadır. Araştırmaya katılan üniversite öğrencilerinin \% 71,4'ünü (n=245) kadın, \% 28,6'sını (n=98) erkek öğrenciler oluşturmaktadır. Çalışmanın veri toplama aşamasında Kendini Sansürleme İsteği Ölçeği, Çocukluk Çağı Travmaları Ölçeği ve Ego Durumları Ölçeği kullanılmıştır. Araştırma verileri, veri toplama araçlarının elektronik ortamda Google Formlar araçlığıyla düzenlenmesiyle çevrimiçi olarak elde edilmiştir. Elde edilen verilerin analiz edilmesi sürecinde korelasyon analizi ve bootstrap yöntemini esas alan regresyon analizi yapılmıștır. Çalışmada Transaksiyonel Analiz kuramındaki ego durumlarından sadece çocuk ego durumunun, çocukluk çağı olumsuz yaşantıları ve kendini sansürleme isteği arasındaki ilişkide aracılık rolü olduğu bulunmuştur. Ayrıca yetişkin ego durumları ve ebeveyn ego durumlarının ise çocukluk çağı olumsuz yaşantıları ile kendini sansürleme isteği arasındaki ilișkide aracılık rolünün olmadığı bulunmuștur. Çalıșma sonucunda elde edilen bulgular ilgili alanyazın çerçevesin de tartışılmıştır. Son olarak ise farklı yaş gruplarındaki bireylerde kendini sansürleme isteğine yönelik farkındalığın artırılması ve kendini sansürleme isteğinin azaltılması için alanda çalışan psikolojik danışmanlara çeşitli önerilerde bulunulmuştur.

Anahtar Kelimeler: çocukluk çağı olumsuz yaşantıları, çocukluk çağı travmaları, kendini sansürleme isteği, ego durumları

Received Date:24 April 2021

Accepted Date:22 June 2021

In this study, it was aimed to examine whether the parent, adult and child ego states in the Transactional Analysis theory ego states model have a mediating effect on the childhood negative experiences of university students and their willingness to self-censorship. The study was organized in accordance with the relational survey model, one of the quantitative research methods. In this context, the study group of the research consists of 343 university students who continue their undergraduate education in different universities and faculties. $71.4 \%(n=245)$ of the university students participating in the research are female and $28.6 \%(n=98)$ are male students. In the data collection phase of the study, the Self-Censorship Willingness Scale, Childhood Trauma Scale and Ego State Scale were used. Research data were obtained online by organizing data collection tools electronically via Google Forms. In the process of analyzing the obtained data, correlation analysis and regression analysis based on the bootstrap method were performed. In the study, it was found that among the ego states in Transactional Analysis theory, only the child ego state had a mediating role in the relationship between childhood negative experiences and the willingness to self-censorship. Besides adult ego states and parental ego states, on the other hand, were found to have no mediating role in the relationship between childhood negative experiences and the willingness to selfcensorship. The findings obtained as a result of the study were discussed within the framework of the relevant literature. Finally, various suggestions were made to psychological counselors working in the field in order to increase awareness of the willingness to self-censorship in individuals of different age groups and to reduce the willingness to self-censorship. Keywords: childhood negative experiences, childhood traumas, willingness to self-censorship, ego states

[1] Doktora Öğrencisi | Düzce Üniversitesi | Rehberlik ve Psikolojik Danışmanlık | Düzce | Türkiye | ORCID: 0000-0003-1158-7735 | onuremrekayabasi@gmail.com 2] Dr. Öğr. Üyesi | Düzce Üniversitesi| Eğitim Fakültesi | Rehberlik ve Psikolojik Danışmanlık | Düzce | Türkiye | ORCID: 0000-0003-4688-6890 


\section{GíRiş}

$\dot{\mathrm{I}}$

nsan düşüncelerini ifade etme isteği olan, anlaşılmaya ihtiyaç duyan psikososyal bir varlıktır. Bireyin bu ihtiyaçlarını giderebilmesi için de başkalarıyla iletişim kurması gerekmektedir (Ekşi vd., 2017). İletişim ise Türk Dil Kurumu (2020) tarafından bireyler arasındaki akla gelebilecek her türlü yol ve yöntemle duygu, düşünce ve bilgi paylaşımı, aktarımı olarak tanımlanmaktadır. Bazen birey gerçekte söylemek istediklerini, düşündüklerini ve hissettiklerini bir süzgeçten geçirerek gizil/örtülü bir iletişim tarzı kullanma eğilimi sergileyebilir. Farklı düşüncelere sahip bazı bireyler sosyal olarak soyutlanma, dışlanma bir başka deyişle sosyal izolasyon endişeleri nedeniyle düşüncelerini gerçekte olduğu gibi açıkça ortaya koyamayabilir (Bayram Saptır, 2020).

Başkalarının onaylamayacağı fikirlerin açıkça dile getirilmesi zaman zaman sosyal olarak reddedilme, sosyal izolasyon, önemli ilişkilerde uyuşmazlıklar ve fiziksel şiddete uğrama gibi sonuçlara neden olabilir (Hayes vd., 2010). Kendini sansürleme isteği bireyin kendi fikirlerini onunla aynı fikirde olmadığını düşündüğü kişilerden yani seyirciden alıkoymayı tercih etmesidir (Hayes vd., 2005a). "Kendini sansürleme" kavramında bireyin konuşmaya başlamadan önce bulunduğu ortamdaki düşünce yapısını değerlendirmesi ve ona göre hareket etmesi söz konusudur. Bu bakımdan kişinin düşüncelerini ifade etme konusundaki genel suskunluk hali olarak tanımlanan "görüş ifadesinin engellenmesi" kavramından ayrılmaktadır (Hayes vd., 2005b). Kendini sansürleme isteği kavramında dikkat edilmesi gereken iki nokta bulunmaktadır. Bunlardan birincisi bireyin kendi fikirleriyle ortamdaki diğer kişilerin fikirleri arasındaki uyuma odaklanmasıyken, ikincisi ise ortamın görüş açıklamaya uygun olmasına rağmen bireyin birtakım sebeplerden dolayı fikirlerini paylaşmayı tercih etmemesidir (Hayes vd., 2005a). Bu noktadan hareketle bir davranışın kendini sansürleme isteği olarak tanımlanabilmesi için, bireyin kendi fikirlerini açık iletişim kullanarak sunabileceği bir ortam ya da durum varken kasıtlı bir şekilde gerçek fikirlerini paylaşmayıp ortamdaki düşüncelere uyum sağlamayı seçmesi gerekmektedir.

Kendini sansürleme isteği bağlamında Noelle-Neumann'ın (1977) Sessizlik Sarmalı Teorisi önemlidir. Bu teoriye göre bireyler çevrelerindeki insanların düşüncelerinin azınlık ya da çoğunluk olması ve ilerleyen süreçte nasıl bir değişim gösterebileceği konusunda kendi içsel süreçlerinde bir değerlendirme yapmaktadır. Bu değerlendirmeyi yaparken aynı zamanda kendi fikirleriyle çevrelerindeki insanların düşüncelerinin uyum düzeyine de bakmaktadırlar. Bu sürecin sonucunda ise kendi gerçek düşüncelerini çevreleriyle paylaşıp paylaşmama konusunda bir seçim yapmaktadırlar (Dolma, 2019). Filak ve arkadaşları (2009) liselerde görev yapan medya danışmanlarının katıldığı çalışmada kendini sansürlemeye eğilimin kişinin kendi korku ve endișelerinden bağımsız bir kişilik özelliği olabileceğini bulmuștur. Bu bağlamda kendi görüşünün çevredekilere uyum sağladığını düşünenler daha aktif bir şekilde fikirlerini beyan edebilirken, 
kendi fikirlerinin çevredekilere uyum sağlamadığını düşünenler paylaşımda bulunmamayı, sessiz kalmayı ya da sözlü-sözsüz yöntemlerle uyum sağlamayı tercih edebilirler.

Öğretmen adaylarının katılımcı olduğu bir araştırmada öğretmen adaylarının kendini sansürleme istekleri ve psikolojik kırılganlıkları arasında orta düzeyde pozitif yönde bir ilişki olduğunu bulmuştur. Ayrıca aynı çalışmada psikolojik kırılganlık değişkeninin tek başına kendini sansürleme isteğinin yordayıcısı olduğu da ortaya konulmuştur (Ekşi vd., 2017). Sıkça siyasi değişimlerin olduğu bir ülke olan Şili'de yapılan bir çalışmada ise siyasi baskı dönemlerinde reşit olan kişilerin daha az siyasi baskının olduğu dönemlerde büyüyen kişilere göre yaşamlarının ilerleyen yıllarda daha fazla kendini sansürleme eğilimi gösterdikleri sonucu bulunmuştur (Etchegaray vd., 2019). Kendini sansürleme isteği ülkemizde ve yurtdışında eğitimde, siyaset psikolojisinde, sosyal medyada, kişiler arası ilişkilerde (Altunok vd., 2017; Arslan, 2015; Bayram Saptır, 2020; Chan, 2018; Dolma, 2019; Ekși vd., 2017; Etchegaray vd., 2019; Filak vd., 2009; Hayes vd., 2010; Spurgin, 2019) olmak üzere pek çok alanda çalışılmıştır. Kendini sansürleme isteğinin iletişim odaklı bir tutum, tercih ya da problem olduğu düşünüldüğünde, hem bireylere patalojik bakışı olan bir psikolojik danışma kuramı hem de kişiler arası iletişimi inceleyen bir iletişim kuramı olarak Transaksiyonel Analiz (TA) ego durumları kavramıyla (Stewart ve Joines, 2019) bireylerdeki kendini sansürleme isteğine farklı bir açılama getirebilir.

Transaksiyonel Analiz (TA) 1950'li yıllarda kanada asıllı ABD’li bir psikanalist olan Eric Berne tarafından geliştirilmiştir (Mitra, 2017). Uluslararası TA kuruluşunun önerdiği tanıma göre TA bireysel olarak değişimi ve gelişimi hedefleyen ve bu amaçla kullanılan sistemli bir kişilik ve psikoterapi kuramıdır (Stewart ve Joines, 2019). Ego durumları, her bir bireyin birbiriyle ilişkili düşünce, duygu ve davranış örüntülerini içeren ve bu örüntüleri Ebeveyn, Yetişkin ve Çocuk sözcükleriyle kümelendiren TA kuramının temel kavramlarından biridir (Cornell vd., 2016). TA kuramının kurucusu Eric Berne (1910-1970) ego durumları üzerine ilk çalışmalarını ABD ordusunda görevli bir psikiyatrist olarak çalıştığı dönemde ortaya koymuştur (Mitra, 2017). Eric Berne, Paul Federn'in belirli zaman dilimlerinde egoda farklı durumların oluştuğu düşüncesini ifade eden ego durumları kavramıyla, Sigmund Freud'un kişiliğin id, ego ve süperego olmak üzere üç ruhsal yapıdan oluştuğu fikrini entegre ederek TA ego durumları modelini oluşturmuştur (Stewart ve Joines, 2019).

Ego durumları modeli, önemli erken çocukluk yaşantılarını (Çocuk), diğer kişilerin önemli etkilerini (Ebeveyn) ve bunların şimdi ve burada yaşanan güncelliğe, gerçekliğe (Yetişkin) entegrasyonunu gösteren bir yapı gösterir. Erken çocukluk döneminde ihtiyaçlarını karşılamada yaşanan önemli başarısızlıklar psikolojik iyi oluşun zayıflamasına, ruhsal ve zihinsel yapıda önemli hasarların oluşumuna neden olabilir (Lister-Ford, 2002). Ego durumları modeli TA analiz kuramında iki şekilde kullanılır. Bunlardan birincisi yapısal analizdir ve bir bireyin kişilik 
yapısının gelişimini bir görüntüsünü, davranışlarının arkasında ne olduğunu (içsel bakış/gözlem) ortaya koymaya çalışır. Diğeri ise fonksiyonel analizdir ve fonksiyonel analiz bireylerin iletişimsel davranışlarını yani bireyin duygularını, düşüncelerini ve davranışlarını şimdi ve burada hangi ego durumunun yönlendirdiğini (dışsal bakış/gözlem) incelemeyi ve anlamayı hedefler (Cornell vd., 2016).

TA kuramına göre ego durumlarındaki yapısal modelde birinci düzey ve ikinci düzey yapısal model bulunmaktadır. Birinci düzey yapısal model ego durumları ebeveyn, yetişkin ve çocuk ego durumları olmak üzere üç ana bölümde sınıflandırılırken, ikinci düzey yapısal modelde çocuk ego durumu çocuktaki ebeveyn (sihirli ebeveyn), çocuktaki yetişkin (küçük profesör) ve çocuktaki çocuk (somatik çocuk) gibi alt bölümlerde incelenmektedir. Fonksiyonel modelde ise çocuk ego durumu kendi içerisinde uygulu çocuk ve doğal çocuk, ebeveyn ego durumu ise eleştirel ebeveyn ve doğal ebeveyn gibi alt sınıflandırmalarla ifade edilebilmektedir (Stewart ve Joines, 2019). Mevcut çalışmada kullanılan Ego Durumları Ölçeği (Özpolat vd., 2015) ego durumlarını kendi içerisinde alt bölümlere ayırmadan birinci düzeyde yapısal modele göre ebeveyn, yetişkin ve çocuk ego durumları olmak üzere üç ana bölümde ele almıştır.

Her insanın içerisinde bir ebeveyn, bir yetişkin ve bir çocuk vardır. Ebeveyn ego durumu küçükken gözlemlenen ve kişinin üzerinde bir izlenim bırakan ebeveyn davranışlarının (anne, baba, amca, teyze, öğretmen gibi) kayıtlarını ve yansımalarını içerir. Bunlar doğrudan bireye ya da başkalarına karşı sergilenmiş olan tutum ve davranışlar olabilir. Bazen bilinçli ya da bilinçsiz olarak bu davranışları tekrar edebiliriz (Mitra, 2017). Ebeveyn ego durumu, "-meli, -malı, her zaman, asla" sözcüklerini sıklıkla kullanma yönelimindedir ve karşı tarafa odaklanır. Ebeveyn ego durumu net direktifler verebileceği gibi karmaşık mesajlar da verebilir (Seligman ve Reichenberg, 2019). Çocuk ego durumu, bireylerin çocukluk döneminde olduğu gibi duygulanım, düşünce ve davranış biçimlerine girmesini yansıtmaktadır (Stewart ve Joines, 2019). Çocuk ego durumunda birey abartılı bir biçimde konuşabilir, benmerkezci olabilir, mızmızlanma, kikirdeme, şımarma benzeri sözel olmayan davranışlar gösterebilir (Seligman ve Reichenberg, 2019). Yetişkin ego durumu ise kişinin çevresinde yaşananlara yani şimdi ve burada olup bitenlere erişkin bir insan olarak yaklaşma becerilerini kullanmasını içermektedir (Stewart ve Joines, 2019). Yetişkin ego durumu bir bilgisayar gibi objektif, gerçekçidir. Mantığı ön plana alarak açık ve net bir biçimde diğer ego durumlarından gelen mesajları kendi çerçevesinde yorumlar, entegre eder ve sorunları çözer (Seligman ve Reichenberg, 2019).

İdeal olan üç ego durumunun (Ebeveyn-Yetişkin-Çocuk) denge halinde olmasıdır. Bu ego durumlarından herhangi birinin baskın ya da çekinik durumda olması, birine ya da ikisine aşırı bağlı olunması ya da bir ego durumunun diğerine bulaşması durumunda ilişkisel problemler başlayabilir (Seligman ve Reichenberg, 2019). Örneğin çok fazla çocuk ego durumunda olan bir 
kişi çevresinde ciddiye alınmayan, patavatsız kişiler olabilirken, çocuk ego durumunu az kullanan birisi de çok sıkıcı, sıradan, enerjisiz görülebilir. Benzer nitelikteki durumlar ebeveyn ve yetişkin ego durumunun çok fazla kullanılması halinde de yaşanabilir. Tüfekçi (2008), Şamatacı (2013) yaptıkları çalışmalarda da bireylerin baskın olarak en çok koruyucu Ebeveyn, en az uygulu çocuk ego durumunu kullandıkları bulmuşlardır. Ayrıca Şamatacı (2013) birey kendisini yetişkin ego durumunda algıladıkça romantik ilişkideki incinme düzeylerinin azaldığını, eleştirel ebeveyn ve doğal çocuk ego durumunda algıladıkça incinme düzeylerinin yükseldiğini bulmuştur. Çam (1999) ise yetişkin ve koruyucu ebeveyn ego durumundaki bireylerin problem çözme becerisini yüksek, doğal çocuk, uygulu çocuk ve eleştirel ebeveyn ego durumundaki bireylerin problem çözme becerisinin düşük olduğunu ortaya koymuştur. Akbağ ve Kulaksızoğlu (2018) yetişkin ego durumunun kendine güvenli yaklaşımla, uygulu çocuk ego durumunun ise kendine güvenmeyen, çaresiz, boyun eğici yaklaşımla ilintili olduğunu ifade etmiştir. Bu çalışmalardan hareketle yetişkin ego durumunun daha problem çözücü, mantıklı, işlevsel olduğu ve genel olarak denge rolü üstlendiği söylenebilir.

21. yy'da da insanlar günlük, sıradan bir olay olarak düzenli bir şekilde travmatik olaylar yaşamaktadır. Bu travmatik olaylar oldukça fazla çeşitlilik göstermektedir. Çocukluk döneminde yaşanan fiziksel istismar veya fiziksel ihmal, duygusal istismar veya duygusal ihmal, cinsel istismar bunlardan bazılarıdır (Basham ve Miehls, 2004). Çocukluk döneminde yaşanan olaylar ve bu olayların etkilerinin yetişkinlik dönemiyle olan ilişkisi ve yansıması açıktır (Roy, 1998). Çocukluk çağı olumsuz yaşantıları baş edilmesi güç bir duruma geldiğinde, etkisi erişkinlik döneminde de devam edebilen ve kişinin hayatını olumsuz etkileyen psikolojik ve davranışsal problemlere sebep olabilir (Janssen vd., 2016). Çocukluk çağı olumsuz yaşantılarıyla ilgili yapılan farklı çalışmalar bu travmaların farklı toplum, kültür ya da sosyoekonomik düzeylerde yaşanabildiğini göstermektedir (Bostancı vd., 2006). Jenkins ve arkadaşları (2021) araştırmalarında üniversite öğrencilerinin çocukluk çağı olumsuz yaşantıları ile olumsuz sosyal deneyimleri (cinsel taciz, taciz, zorbalık gibi) arasında pozifif yönlü ilişkiler olduğunu belirtmiştir. Ayrıca çocukluk çağı olumsuz yaşantılarının depresyon ve stres gibi zorlu duygu durumlarıyla baş etmeyi zorlaştırdığı bulunmuştur. Gündüz ve Gündoğmuş (2019) yaptıkları çalışmada çocukluk çağı olumsuz yaşantıları olan yetişkinlerin daha fazla olumsuz otomatik düşünceleri, uyumsuz şemaları, işlevsel olmayan tutum ve davranışları olduğunu bulmuşlardır. Ayrıca çocukluk çağı olumsuz yaşantıların varlığı bireydeki depresyon ve anksiyete şiddetini artırmaktadır. Majör depresif tanısı konan ve intihar girişiminde bulunan ve bulunmayan hastaların yer aldığı bir çalışmada çocukluk çağı olumsuz yaşantıları ve intihar girişimi arasındaki ilişkide psikolojik acının ve dissosiyasyonun tam aracı rolü olduğu bulunmuştur (Demirkol vd., 2020). Daha önce ifade edildiği gibi Şili'de siyasi baskı ile yetişen kuşakda da kendini sansürleme davranışı vardı. 
Yani çocukluk çağı olumsuz yaşantılar ile birlikte zorlu yaşam olaylarının da psikolojik sağlamlığı (Çetin, 2020), kendini sansürleme isteğini (Etchegaray vd., 2019) etkileyebildiği görünmektedir.

TA ego durumları, bireylerin doğrudan düşünce, duygu ve davranış örüntüleriyle ilişkili bir kavramdır. Bireyler kişiliklerinin belli bir kısmını ego durumlarıyla sergilerler (Kılıçarslan, 2019). Çocukluk döneminde alınan erken dönem kararları, kişiliği ve bireyin yetişkinlikteki duygudurumlarını, düşüncelerini ve davranışlarını belirlemektedir (Stewart ve Joines, 2019). Bu bağlamda bireylerin çocukluk çağı olumsuz yaşantılarının gündelik yaşamdaki kendini sansürleme isteği ile ilişkili olabileceği ve ego durumlarının kullanımının bu durumu nasıl etkileyebileceğini araștırma düșüncesi bu çalıșmanın çıkıș noktasını olușturmuștur. Bu çalıșmada üniversite öğrencilerinin çocukluk çağı olumsuz yaşantıları ve kendini sansürleme isteğinde ego durumlarının aracılık etkisinin olup olmadığı araștırmak amaçlanmıștır. Hem ülkemizde hem de yurtdışında kendini sansürleme isteği ile ilgili psikolojik danışma alanında yeterince çalışma olmadığı görülmektedir. Literatürde birbiriyle ilişkili olabileceği düşünülen çocukluk çağı olumsuz yaşantıları, kendini sansürleme isteği ve ego durumları kavramının birlikte çalışıldığı bir çalışmaya rastlanmamıştır. Bu çalışmanın alandaki bu açığı gidermeye yardımcı olacağı düşünülmektedir.

\section{YÖNTEM}

\section{Araştırmanın Modeli}

Araştırmada nicel araştırma yöntemlerinden ilişkisel tarama modeline dayalı yordayıcı korelasyonel model (Büyüköztürk vd., 2012) kullanılmıştır. Üniversite öğrencilerinin çocukluk çağı olumsuz yaşantıları ile kendini sansürleme istekleri arasındaki ilişkide TA yaklaşımında yer alan ego durumlarının aracılık rolü incelenmiş ve bu kapsamda aşağıdaki hipotezler test edilmiştir.

H1= Üniversite öğrencilerinin çocukluk çağı olumsuz yaşantıları ile kendini sansürleme istekleri arasındaki ilişkide ebeveyn ego durumunun aracılık rolü vardır.

H2= Üniversite öğrencilerinin çocukluk çağı olumsuz yaşantıları ile kendini sansürleme istekleri arasındaki ilişside yetişkin ego durumunun aracılık rolü vardır.

H3= Üniversite öğrencilerinin çocukluk çağı olumsuz yaşantıları ile kendini sansürleme istekleri arasındaki ilişkide çocuk ego durumunun aracılık rolü vardır.

\section{Çalışma Grubu}

Araştırmanın örnekleme modeli, seçkisiz olmayan örnekleme yöntemlerinden olan uygun (kolayda) örnekleme modelidir. Uygun (kolayda) örnekleme örneklemin zaman, para ve işgücü 
yönünden kolay ulaşılabilir ve uygulanabilir birimlerden seçilmesidir (Büyüköztürk vd., 2012). Araştırmaya katılım gönüllük esasıyla sağlanmıştır. Araştırmanın çalışma grubunu farklı üniversitelerde ve fakültelerde lisans öğrenimini sürdüren 343 üniversite öğrencisi oluşturmaktadır. Araştırmaya katılan üniversite öğrencilerinin \% 71,4'ünü (n=245) kadın, \% 28,6’sını (n=98) erkek öğrenciler oluşturmaktadır.

\section{Verilerin Toplanması}

Araştırma verileri, ölçeklerin elektronik ortamda Google Formlar aracılığıyla düzenlenmesiyle çevrimiçi olarak elde edilmiştir. Verilerin toplanması 10 günde tamamlanmıştır.

\section{Veri Toplama Araçları}

Çocukluk Çağı Travmaları Ölçeği (Gözden Geçirilmiş ve Genişletilmiş Versiyonu). Çocukluk Çağı Travmaları Ölçeği Bernstein ve arkadaşları (1994) tarafından geliştirilmiştir. Ölçeğin Türkçeye uyarlanan 28 maddeden oluşan ilk versiyonunun geçerlik ve güvenilirlik çalışmaları Şar ve arkadaşları (2012) tarafından yapılmıştır. Bu çalışmada kullanılan, 33 madde ve 6 faktörlü bir yapıdan oluşan Çocukluk Çağı Travmaları Ölçeği Gözden Geçirilmiş ve Genişletilmiş Versiyonu'nun geçerlik ve güvenilirlik çalışmaları ise Şar ve arkadaşları (2021) tarafından yapılmıştır. Ölçeğin Cronbach Alpha güvenilirlik katsayısı 87 bulunmuştur. Duygusal taciz, fiziksel taciz, duygusal istismar, fiziksel İstismar, cinsel taciz ve aşırı koruma-kontrol şeklinde alt boyutları bulunmaktadır. Her bir alt boyutun puanlarının toplamı toplam çocukluk çağı travmaları puanını oluşturmaktadır. Toplam puan ölçeğin genişletilmiş versiyonu için 25-150 puan aralığındadır. Ölçekte ters puanlanması gereken maddeler bulunmaktadır $(1,2,4,5,7,10$, $13,19,26,28,31)$. Ayrıca ölçekte inkar maddeleri olarak yer alan maddeler $(10,16,22)$ ise toplam puana etki etmemektedir (Şar vd., 2021).

Kendini Sansürleme İsteği Ölçeği. Hayes ve arkadaşları (2005b) tarafından 5’li likert tipinde geliştirilen 8 maddelik bir ölçektir. Ölçeğin Türkçeye uyarlanması ve geçerlik güvenilirlik çalışmaları Coşkun ve arkadaşları (2012) tarafından yapılmıştır. Ölçek tek faktörlü bir yapıda olmakla birlikte ölçekte ters madde olarak kodlanması gereken maddeler $(4,8)$ bulunmaktadır. Ölçeğin Cronbach Alpha güvenilirlik katsayısı .83 ve iç tutarlılık katsayısı ise .92 bulunmuştur.

Ego Durumları Ölçeği. Özpolat ve arkadaşları (2015) tarafından TA kuramı tabanlı bir kavram olan ego durumlarını ölçme amacıyla üniversite öğrencileri örneklemiyle geliştirilmiștir. Ölçek toplam 17 maddeden oluşmaktadır. Yapılan faktör analizinde ölçeğin \% 40'ını açıklayan 3 alt boyutlu bir yapı ortaya çıkmıştır. Bu alt boyutlar Ebeveyn ego durumu (7 madde), Yetişkin ego 
durumu (6 madde) ve Çocuk ego durumu (4 madde) olarak ifade edilmektedir. Ölçeğin Cronbach Alpha güvenilirlik katsayısının .84 olduğu bulunmuştur.

\section{Verilerin Analizi}

Çocukluk çağı olumsuz yaşantıları ile kendini sansürleme isteği arasındaki ilişkide ego durumlarının aracı rolünü test etmek amacıyla Hayes (2018) tarafından geliştirilen Process Macro programı kullanılmıştır. Dolaylı, düzenleyici ve durumsal aracı etkilerin daha kolay ve pratik şekilde yapılabilmesi ve aracı etkiye ilişkin hipotezlerin, Bootstrap tekniği ile elde edilen güven aralıklarına göre sınanabilmesi nedeniyle Process Macro programı tercih edilmiştir. Bootstrap tekniğine dayalı analizlerin aracılık modellerinde daha geçerli ve güvenilir sonuçlar verdiği bilinmektedir (Fritz ve MacKinnon, 2007, akt. Gürbüz, 2019)

Analizlerin öncesinde normallik, çoklu ortak doğrusallık, artıkların bağımsızlığı, uç değerler vb. regresyon analizi yapabilmek için gerekli önkoşullar kontrol edilmiş ve herhangi bir ihlalin olmadığı görülerek analizler yürütülmüştür.

\section{Etik Onay}

Çalışmanın etik kurul onayı Düzce Üniversitesi Bilimsel Araştırma ve Yayın Etik Kurulu tarafından 2020/221 karar sayılı ve 03.12.2020 tarihli onay ile verilmiștir.

\section{BULGULAR VE YORUM}

Çalışmanın değiş̧kenleri arasındaki ilişkileri belirlemek amacıyla Pearson Momentler korelasyon analizi yapılmış ve sonuçları Tablo 1'de verilmiştir.

\section{Tablo 1}

Korelasyon Analizi Sonuçları

\begin{tabular}{|c|c|c|c|c|}
\hline Değişkenler & 1. & 2. & 3. & 4. \\
\hline \multicolumn{5}{|c|}{ 1. Çocukluk Çağı Olumsuz Yaşantılar } \\
\hline 2. Kendini Sansürleme İsteği & $.141^{* *}$ & & & \\
\hline 3. Çocuk Ego Durumu & $.324^{* *}$ & $.383^{* *}$ & & \\
\hline 4. Yetişkin Ego Durumu & $-.178^{* *}$ & $-.113^{*}$ & .056 & \\
\hline 5. Ebeveyn Ego Durumu & .007 & -.041 & $.130^{*}$ & $.354^{* *}$ \\
\hline
\end{tabular}

Tablo 1 incelendiğinde üniversite öğrencilerinin çocukluk çağı olumsuz yaşantıları, kendini sansürleme isteği ve ego durumları arasında anlamlı ilişkiler olduğu görülmektedir. Çocukluk çağı olumsuz yaşantılar ile kendini sansürleme isteği $(r=.141, p<.01)$ arasında pozitif yönde anlamlı bir ilişki, çocukluk çağı olumsuz yaşantıları ile çocuk ego durumu $(r=.324, p<.01)$ arasında pozitif yönlü anlamlı bir ilişki, çocukluk çağı olumsuz yaşantıları ile yetişkin ego durumu ( $\mathrm{r}=-.178, \mathrm{p}<.01)$ negatif yönlü anlamlı bir ilişki bulunmuştur. Çocukluk çağı olumsuz yaşantılar ile 
ebeveyn ego durumu arasında anlamlı bir ilişki bulunmamıștır. Ayrıca kendini sansürle isteği ile çocuk ego durumu (r= .383, p<.01) arasında pozitif yönlü bir ilişki bulunmuştur.

Çocukluk çağı olumsuz yaşantıları ile kendini sansürleme isteği arasındaki ilişkide yetişkin, ebeveyn ve çocuk ego durumlarının aracı rolünü test etmek amacıyla Bootstrap yöntemini esas alan regresyon analizi yapılmıștır. Analizlerde bootstrap tekniği ile 5000 yeniden örneklem seçeneği tercih edilmiştir. Bootstrap tekniği ile yapılan aracılık etki analizlerinde, araştırma hipotezinin desteklenebilmesi için analiz neticesinde elde edilen \%95 güven aralığındaki (confidence interval, CI) değerlerin sıfır (0) değerini kapsamaması gerekmektedir (MacKinnon vd., 2004, akt.Gürbüz, 2019). Araştırma hipotezlerinin test edilmesiyle elde edilen bulgular aşağıda verilmiştir.

Araştırmanın birinci hipotezi olan üniversite öğrencilerinin çocukluk çağı olumsuz yaşantıları ile kendini sansürleme istekleri arasındaki ilişkide ebeveyn ego durumunun aracılık rolüne ilişkin bulgular Şekil 1'de sunulmuştur.

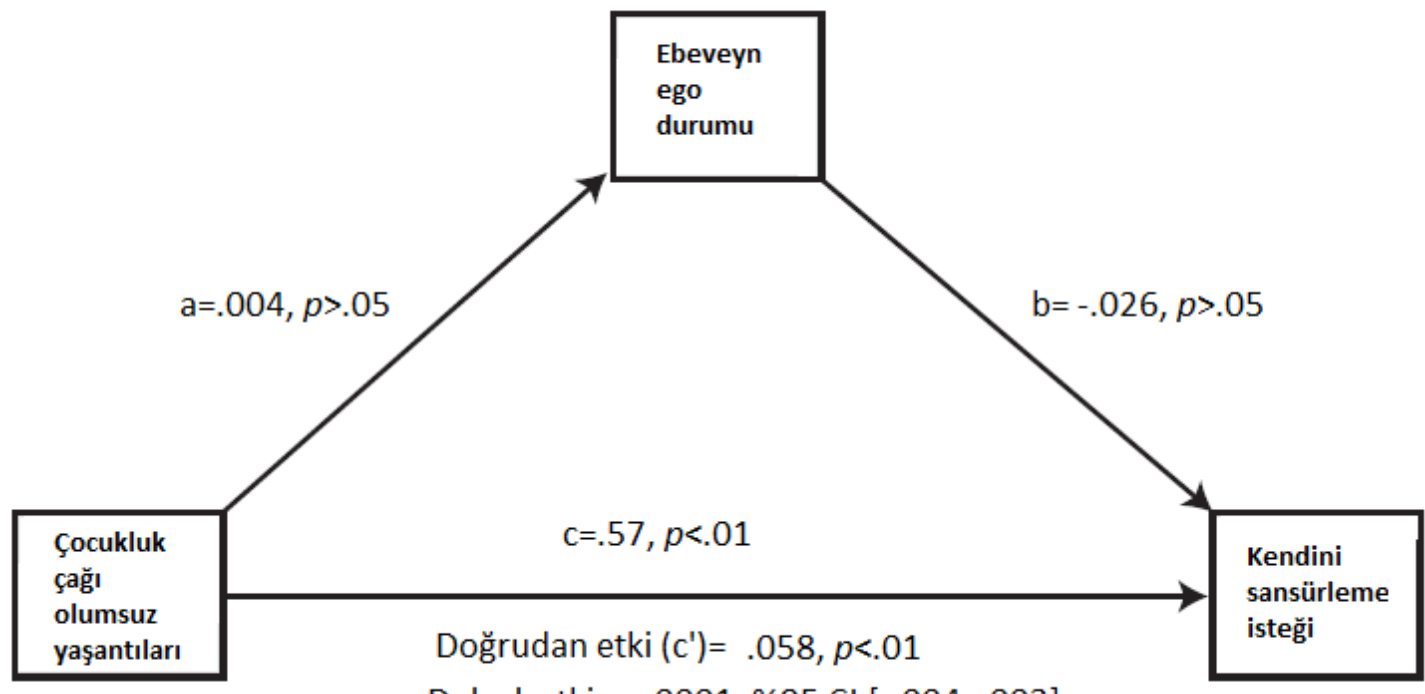

Not: Standardize edilmemiş beta katsayıları raporlanmıștır.

Şekil 1. Çocukluk Çağı Olumsuz Yaşantıları ile Kendini Sansürleme Arasındaki İlişkide Ebeveyn Ego Durumunun Aracılık Rolü (N=343)

Şekil 1'de görüldüğü gibi çocukluk çağı olumsuz yașantılarıyla kendini sansürleme isteği arasındaki ilişkide ebeveyn ego durumunun aracılık rolü istatistiksel olarak anlamlı değildir $(b=$ $.0001, \% 95$ BCA CI [-.004,.003]). Bu bulguya göre araştırmanın birinci hipotezi doğrulanmamıştır.

Araştırmanın ikinci hipotezi olan üniversite öğrencilerinin çocukluk çağı olumsuz yaşantıları ile kendini sansürleme istekleri arasındaki ilişkide yetişkin ego durumunun aracılık rolüne ilişkin bulgular Şekil 2'de sunulmuştur. 


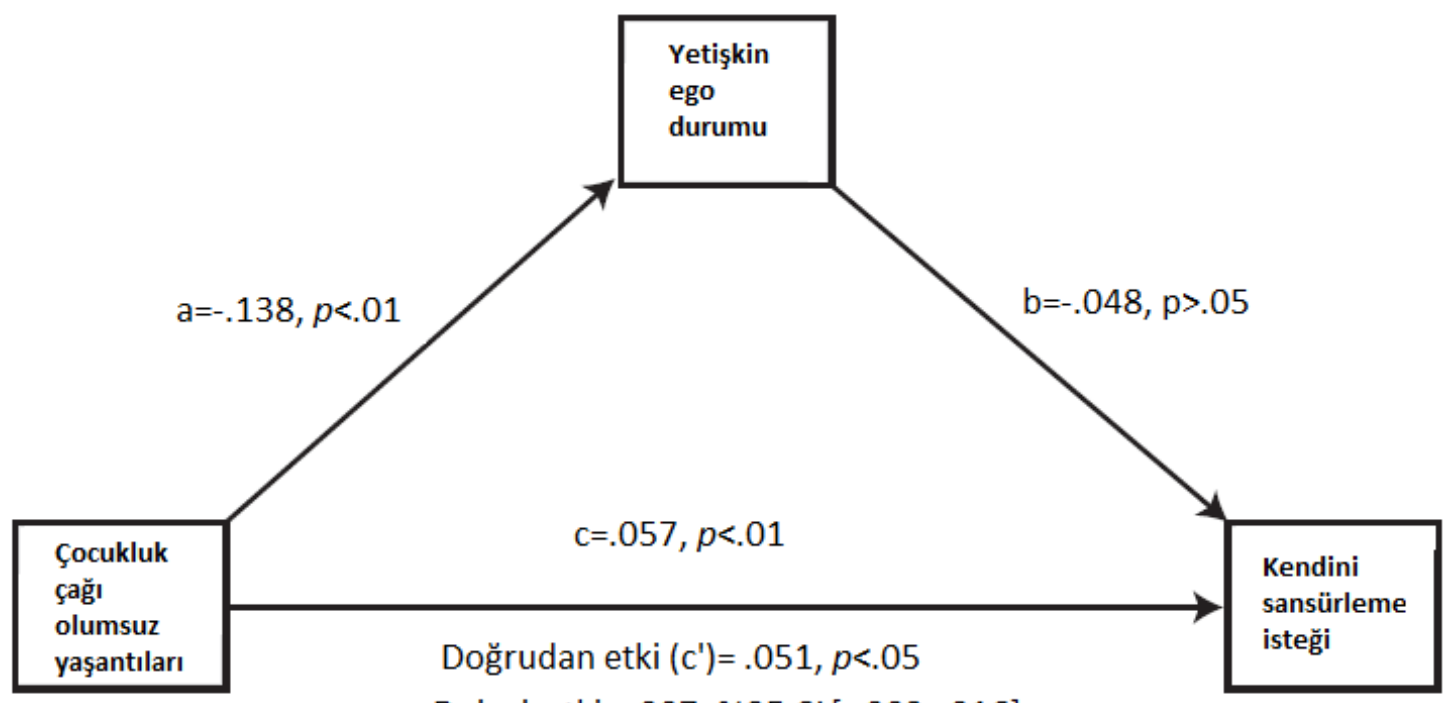

Dolaylı etki $=.007, \% 95 \mathrm{Cl}[-.002, .016]$

Not: Standardize edilmemiș beta katsayıları raporlanmıștır.

Şekil 2. Çocukluk Çağı Olumsuz Yaşantıları ile Kendini Sansürleme Arasındaki İliş̧kide Yetişkin Ego Durumunun Aracıllk Rolü (N=343)

Şekil 2'de görüldüğü gibi çocukluk çağı olumsuz yaşantıları ile kendini sansürleme isteği arasındaki ilişkide yetişkin ego durumunun aracılık rolü istatistiksel olarak anlamlı değildir $(b=$ $.007, \% 95$ BCA CI [-.002, .016]). Bu bulguya göre araştırmanın ikinci hipotezi doğrulanmamıştır.

Araştırmanın üçüncü hipotezi olan çocukluk çağı olumsuz yaşantıları ile kendini sansürleme isteği arasındaki ilişkide çocuk ego durumunun aracılık rolüne ilişkin bulgular Şekil 3'de sunulmuştur.

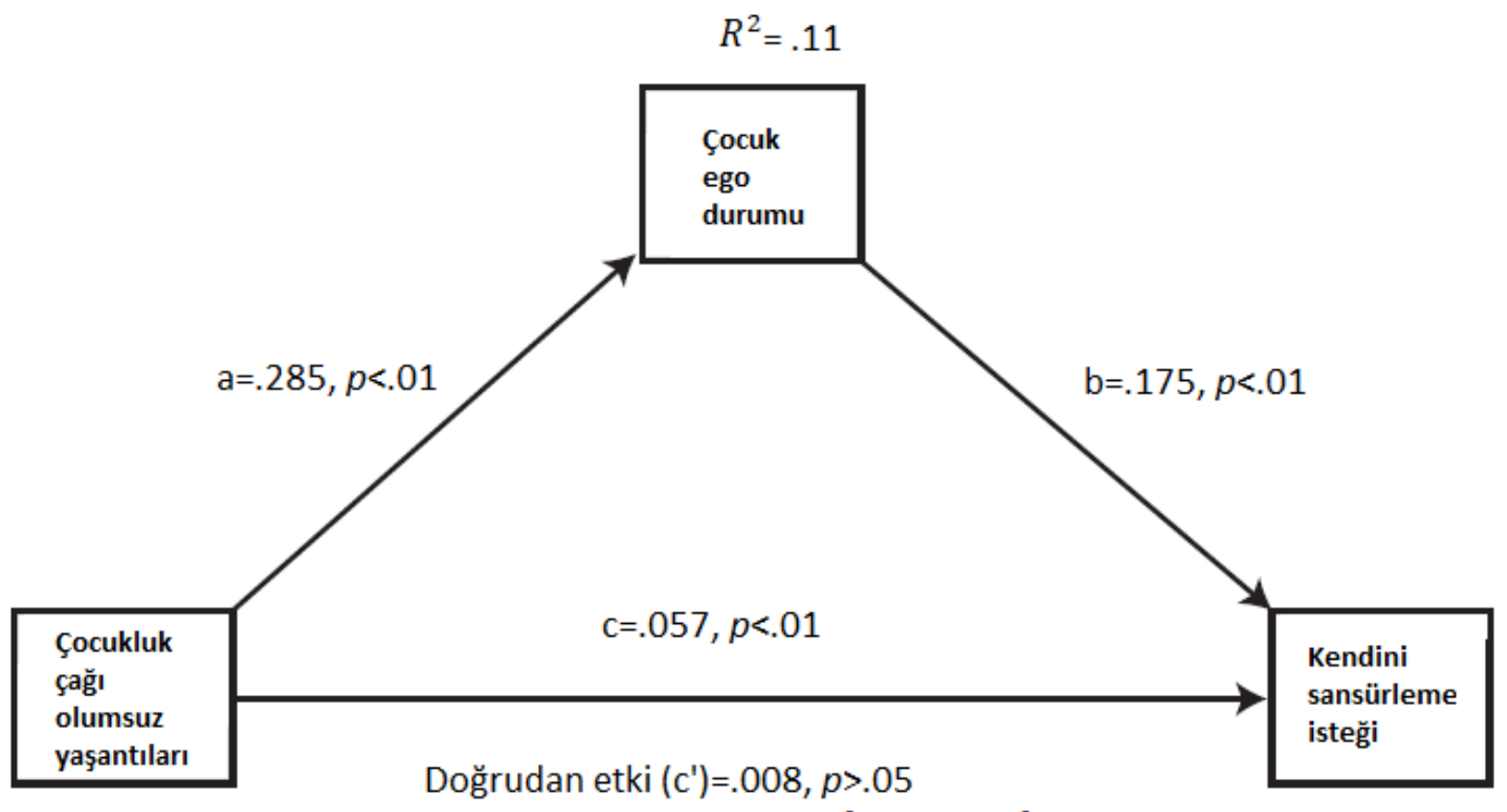

Dolaylı etki $=.050, \% 95 \mathrm{Cl}[.030, .076]$ 
Not: Standardize edilmemiş beta katsayıları raporlanmıştır. $\boldsymbol{R}^{2}$ değeri, açıklanan varyansı göstermektedir.

Şekil 3. Çocukluk Çağı Olumsuz Yaşantıları ile Kendini Sansürleme Arasındaki İlişkide Çocuk Ego Durumunun Aracılık Rolü (N=343)

Şekil 3'de görüldüğü gibi çocukluk çağı olumsuz yaşantılarıyla kendini sansürleme isteği arasındaki ilişkide çocuk ego durumunun aracılık rolü vardır, değişkenler arasındaki dolaylı etki anlamlıdır ( $b=.050, \% 95$ BCA CI $[.030, .075])$. Zira bootstrap analizi neticesinde düzeltilmiş yanlılık ve hızlandırılmış güven aralığı değerleri (BCA CI) 0 (sıfır) değerini kapsamamaktadır. Aracılık etkisinin tam standardize etki büyüklüğü $\left(K^{2}\right) .12$ olup bu değerin orta değere yakın bir etki büyüklüğü olduğu söylenebilir. Bu sonuçlara ışığında araştırmanın üçüncü hipotez doğrulanmıştır.

\section{TARTIŞMA, SONUÇ VE ÖNERÍLER}

Bu çalışmada TA ego durumlarından sadece çocuk ego durumunun çocukluk çağı olumsuz yaşantılar ile kendini sansürleme isteği arasında aracılık rolünün olduğu bulunmuştur. Baron ve Kenny (1986) tarafından aracı değişken, bağımsız değişkenin bağımlı değişken üzerindeki etkisini artıran değişken olarak ifade edilmektedir. Bu bağlamda ego durumlarından çocuk ego durumunun üniversite öğrencilerinin çocukluk çağı olumsuz yaşantıları ile kendini sansürleme istekleri arasındaki ilişkide aracı rolünün bulunması, çocuk ego durumu kullanım düzeyinin çocukluk çağı olumsuz yaşantılarının kendini sansürleme isteği üzerindeki yordayıcılığını artırdığı ya da güçlendirdiği şeklinde yorumlanabilir. Çalışmadaki değişkenler arası ilişkilere bakıldığında ise üç değişkenin de birbirleriyle farklı düzeylerde ilişkili olduğu görülmektedir. Üniversite öğrencilerinin çocuk ego durumu puanlarının hem çocukluk çağı olumsuz yaşantıları puanları hem de kendini sansürleme isteği puanlarıyla pozitif yönde anlamlı ilişkileri olduğu düşünüldüğünde çocuk ego durumunun anlamlı güven aralığında bir aracı değişken olması beklenen bir sonuç olarak görülebilir.

Birey erken çocukluk yıllarında aile içerisinde kendisine izin verilen ve yasaklanan bazı duygular olduğunu fark ederek temas iletileri almak amacıyla yaşam kurgusu içerisinde sadece izin verilen duyguları yaşamaya karar verebilir. Otantik duyguların yerine geçen bu duygular raket duygular olarak tanımlanmaktadır (English, 1971; Akt. Kılıçarslan, 2019). Bu bağlamda çocuk ego durumunda birey kimi zaman ebeveynlerinin beklentilerini karşılamak, isteklerini yerine getirmek ve olumlu temas iletileri alabilmek için gerçekte olmadığı gibi duygu, düşünce ve davranış örüntüleri sergileyebilir. Örneğin, çocuk komşularını çok sevmese de uyulması gereken bir kural olarak herhangi bir konuda onlara yardım etmeyi ya da yolda gördügünde selam verip sohbet etmeyi tercih edebilir. Bu örnekten hareketle bireyin kimi durumlarda duygu, düşünce ve davranışlarının onaylanmayacağını öngördüğünde, duygu, düşünce ve davranışlarını açıkça sergileyememeyi tercih ederek kendini sansürlediği düşünülebilir. Dolayısıyla çocuk ego 
durumunda kullanılan raket duyguların çocukluk çağı olumsuz yaşantıları ile kendini sansürleme isteği arasındaki ilişkiyi artırdığı düşünülebilir.

Travma sadece durumsal bir yaşantı değil, aynı zamanda zaman içerisinde gelişen, değișen uzun vadeli bir psikososyal süreçtir (Akcan, 2018). Oflaz (2015) hayat boyunca görülen travmaların \% 25'inin çocukluk yıllarında gerçekleştiğini ifade etmektedir. Çocukluk çağı olumsuz yaşantıları olan bireyler travmatik durumla baş etmede zorlandıklarında çocuk ego durumunu daha fazla kullanıyor olabilirler. Bu noktadan hareketle çocukluk çağı olumsuz yaşantı puanları daha yüksek olan bireylerde çocuk ego durumu kullanımının kendini sansürlemede aracı değişken olması çocuk ego durumunun ebeveyninin onayını ve takdirini almak isteyen ya da acıdan, yüzleşmeden kaçınan yönüyle ilişkili olabilir. Ebeveynlerinden yeterince temas iletisi almayan bireylerde kendini ifade etmede zorluk, kendisine veya çevreye güven problemleri, öz saygı düşüklüğü, samimi ilişki ya da arkadaşlık kuramama, stresle baş etmede güçlük gibi durumlar yaşanabilir. Ayrıca çocukluk çağı olumsuz yaşantıları olan bireyler bu durumdan kendilerini sorumlu tutabilirler. Bu durumlar bireydeki kendini sansürleme isteğine ortam hazırlayan faktörler olarak yorumlanabilir. Üniversite öğrencilerinin stresle başa çıma tarzları ve ego durumları arasındaki ilişkileri incelemeyi amaçlayan bir çalışmada kendine güvenli olan yaklaşımı en fazla benimseyen grubun yetişkin ego durumu, en az benimseyenlerin ise uygulu çocuk ego durumunu daha yoğun kullandıkları bulunmuştur (Akbağ ve Kulaksızoğlu, 2018). Ayrıca Hayes ve arkadaşları (2005a) çalışmalarında kişinin kendini sansürleme isteğinin artmasında öz saygısının düşmesinin rolü olduğunu bulmuşlardır. Güneri Yöyen (2017) üniversite öğrencilerinin katılımcı olduğu araştırmasında çocukluk çağı olumsuz yaşantılar ve benlik saygısı arasında negatif yönlü düşük düzeyde bir ilişki bulmuştur. Chan (2018) HongKong'da vatandaşların yüz yüze ve facebook ortamında siyasi görüşünü açıklama istekliliğini araştırdığı çalışmada sosyal izolasyon korkusunun her iki iletişim ortamı için de kendini sansürleme isteğini artırdığını bulmuştur. Çocukluk çağı olumsuz yaşantıları olan bireyler kendilerini değersiz, suçlu hissettikleri için sosyal çevreleri tarafından dişlanma korkusu yaşayabilirler. Çocukluk çağı olumsuz yaşantıları olan bireylerin hissettikleri bu değersizlik ve suçluluk hissi, çocuk ego durumunu daha fazla kullanmalarına ve sosyal ilişkilerinde kendini sansürleme eğiliminde olmalarına neden oluyor olabilir. Matthes ve arkadaşları (2012) de sosyal izolasyon korkusu olan bireylerin kendini sansürleme isteklerinin daha fazla olduğunu ifade etmişlerdir. Toplumdan dışlanma korkusuyla ebeveynlerinin beklentilerine ve isteklerine koşulsuz kabul eden ve raket duygular yaşayan dolayısıyla da çocuk ego durumunu daha yoğun kullanan bireylerin kendini sansürleme isteği daha çok olabilir.

Mevcut çalışmada ebeveyn ego durumu ve yetişkin ego durumunun çocukluk çağı olumsuz yaşantılar ile kendini sansürleme isteği arasında aracılık etmediği bulunmuştur. Ebeveyn ego 
durumu bireyin erken çocukluk ylllardan itibaren hem ailesinde hem de sosyal çevresinde karşılaştığı kuralları, kalıp yargıları, izin verilen ya da yasaklanan duygu, düşünce ve davranış durumlarını içselleştirdiği şekilde yansıttığı, daha çok çevreyi kontrol etme odaklı ve korumacı yönünü yansıtmaktadır (Stewart ve Jones, 2019). Çocukluk çağında olumsuz yaşantıları olan bireyler krizle baş etme yöntemi olarak aşırı kontrol etme, kural koyma gibi eğilimlerde bulunabilir. Bu durum ebeveyn ego durumun çocukluk çağı olumsuz yaşantılar ile kendini sansürleme isteği arasındaki ilişkide aracılık etmemesini açılayabilir.

Yetişkin ego durumu bireyin çevresinde olup bitenleri mantık çerçevesinde yorumlayıp değerlendirdiği, kişiliğinin gerçekçi, otantik ve bütünleştirici yönünü yansıtmaktadır (Stewart ve Joines, 2019). Çocukluk çağı olumsuz yaşantısı olan bireyler yetişkin ego durumunda olduklarında, mevcut durum ve gerçekliği nesnel veriler işleyerek algılayıp șimdi ve burada kalarak, problemle baş etmek için farklı seçenekleri olabileceğini fark ederler. Bu durumda birey yetişkin ego durumunu kullandığında kendini sansürleme isteği olmayabilir. Yetişkin ego durumunun problemle baş etme yönlü bir ego durumu olması çocukluk çağı olumsuz yaşantılar ile kendini sansürleme isteğine aracılık etmemesini açıklayabilir. Diğer taraftan travma sonrası büyüme Calhoun ve arkadaşları (2000) tarafından önemli bir yaşam krizi ile baş etmeye çalışırken bireyde gelişen olumlu değişimler olarak tanımlanmaktadır. Çocukluk çağı olumsuz yaşantıları olan bireylerden travma sonrası büyüme yaşayanların daha fazla yetişkin ego durumu kullanıyor olabilecekleri düşünülmektedir. Dolayısıyla yetişkin ego durumunun çocukluk çağı olumsuz yaşantıları ile kendini sansürleme isteğinde aracılık etmemesi üniversite öğrencilerinin travma sonrası büyümeye bağlı olarak yetişkin ego durumunu daha sık kullanmalarıyla ilişkili olabilir.

Ayrıca üç ego durumu içerisinde değişime en açık olan ego durumu yetişkin ego durumudur (İkiz, 2016). Bu nedenle yetişkin ego durumunu daha fazla kullanan yetişkinlerin sosyal bir ortamda değişik ve farklı fikirler ortaya sunmaktan diğer ego durumlarına göre daha az çekineceği düşünülebilir. Böylece travmatik durumlarla baş etmede farklı seçeneklere yönelmeye, yeni durumlara uyum sağlamaya veya gerektiğinde değișik yollar denemeye daha açlk olurlar. Bu durum yetişkin ego durumunda kendini sansürleme davranışının daha az olması beklenebilir.

Sonuç olarak TA hem bir iletişim kuramı hem de psikopatolojisi olan bir psikolojik danışma kuramıdır (Stewart ve Joines, 2019). Bu noktadan hareketle insanlar gündelik yaşamlarında ebeveyn, yetişkin ve çocuk ego durumları arasında olaya, duruma ve kişiye bağlı olarak geçişler yaparlar. Sağlıklı olan ve beklenen bu ego durumlarının dengeli kullanılmasıdır. $\mathrm{Bu}$ araştırmada bireyin çocukluk dönemindeki duygu, düşünce ve davranış örüntülerini içeren çocuk ego durumunun çocukluk çağı olumsuz yaşantılarıyla kendini sansürleme isteği arasındaki ilişkide aracı değişken olduğu bulunmuştur. Çocukluk çağı olumsuz yaşantılar kendini sansürleme isteğini artıran faktörlerden biri olabilir. Bu noktada bireyin doğum öncesi döneminden itibaren 
sağlıklı gelişiminden sorumlu olan birincil bakım verenlerin, sağlıklı ebeveyn tutumları sergileyerek, çocukla etkili iletişim ve güvenli bağlanma stilleri kurarak bireyin üç ego durumunu da dengeli kullanmasına yardımcı olacak bir rol model oluşturmalıdır. Başka bir deyişle çocukluk çağı olumsuz yaşantılarına yol açabilecek risk faktörlerinin başta bakım veren ve çocukla ilgili diğer kişi ve kurumlarca ortadan kaldırılmasına yönelik önleyici çalışmalar, çocukluk çağına ilişkin koruyucu faktörlerin aktifleştirilmesi, bireyin gelecek yaşantısında uygun ve dengeli bir şekilde ego durumlarını kullanmasına yardımcı olacağı düşünülmektedir. Böylece psikososyal bir varlık olan bireyin iletişim ortamların kendini sansürleme ihtiyacının azalacağı düşünülmektedir. Ayrıca alanda çalışan psikolojik danışmanlar tarafından çocukluk çağı olumsuz yaşantıları olan bireylerin ego durumlarını dengeli kullanımlarını düzenlenmesi, kendini sansürleme davranışı ile ilgili farkındalık kazandırılması amacıyla farklı yaş gruplarına yönelik olarak transaksiyonel analiz kuramı temelli grupla psikolojik danışma, psikoeğitim çalışmaları, bireysel psikolojik danışma gibi müdahale çalışmaları yapılması önerilebilir. Bu çalışmaların etkililikleri deneysel yöntem kullanılarak sınanabilir. Çocukluk çağı olumsuz yaşantılar ve kendini sansürleme isteği arasında aracılık etkisi olabilecek başka önemli değişkenlerin neler olabileceği araștırılabilir.

\section{KAYNAKÇA}

Akbağ, M., \& Kulaksızoğlu, A. (2018). Üniversite öğrencilerinde stresle başa çıkma: Transaksiyonel analiz ego durumları bağlamında bir inceleme. Uluslararası Toplum Araștırmaları Dergisi, 9(16), 53-78. https://doi.org/10.26466/opus.476576

Akcan, G. (2018). Travmanın psikolojik bileșenleri-Post travmatik stres bozukluğu. O. Celbiș (Ed.), Turaz Akademi 2018 (ss. 47-53). Akademisyen Kitabevi.

Altunok, Ö., Buzluk, P., Çalıkuşu, F. A., Çoban, M. Ş., Çongar Y., Epik, S., Küçük, O., Oral, S., Polat, M., \& Yıldırım, 0. (2017). Türkiye'de Sansür ve Otosansür. Tunç Yayıncılık. http://susma24.com/wp-content/uploads/2019/02/mehtap-susma-turkce.pdf

Arslan, Ç. (2015). Kendini sansürleme ve etkileşim kaygısının beyin fırtınasında yaratıcılı̆ga etkisi [Yayımlanmamış yüksek lisans tezi]. Abant İzzet Baysal Üniversitesi.

Bahadır, E., Astar, M., \& Anlı, İ. (2020). Erken dönem uyumsuz şemaları ile savunma düzenekleri arasındaki ilişkilerin çocukluk çağı travmaları açısından incelenmesi. Anadolu Psikiyatri Dergisi, 21(3), 237-244. https://doi.org/10.5455/apd.58804

Baron, R. M., \& Kenny, D. A. (1986). The moderator-mediator variable distinction in social psychological research: Conceptual, strategic, and statistical considerations. Journal of Personality and Social Psychology, 51(6), 1173-1182. https://doi.org/10.1037//00223514.51.6.1173

Basham, K. K., \& Miehls, D. (2004). Transforming the Legacy: Couple Therapy with Survivors of Childhood Trauma. Columbia University Press. http://ebookcentral.proquest.com 
Bayram Saptır, A. (2020). Sosyal medya bağımlılığı ve kendini sansürleme: Bazı değişkenler açısından incelenmesi [Yayımlanmamış yüksek lisans tezi]. Sakarya Üniversitesi.

Bernstein, D. P., Fink, L., Handelsman, L., Foote, J., Lovejoy, M., Wenzel, K., Sapareto, E., \& Ruggiero, J. (1994). Initial reliability and validity of a new retrospective measure of child abuse and neglect. American Journal of Psychiatry, 151(8), 1132-1136. https://doi.org/10.1176/ajp.151.8.1132

Bostancı, N., Albayrak, B., Bakoğlu, İ., \& Çoban, Ş. (2006). Üniversite öğrencilerinde çocukluk çağı travmalarının depresif belirtileri üzerine etkisi. Yeni Sempozyum Dergisi, 44(2), 100-106. http://yenisymposium.com/Pdf/TR-YeniSempozyum-759d6a7b.pdf

Büyüköztürk, Ş., Kılıç Çakmak, E., Akgün, Ö. E., Karadeniz, Ş., \& Demirel, F. (2012). Bilimsel Araştırma Yöntemleri (11. baskı). Pegem Akademi Yayınları.

Calhoun, L. G., Cann, A., Tedeschi, R. G., \& McMillan, J. (2000). A correlational test of the relationship between posttraumatic growth, religion, and cognitive processing. Journal of Traumatic Stress, 13(3), 521-527. https://doi.org/10.1023/a:1007745627077

Chan, M. (2018). Reluctance to talk about politics in face-to-face and facebook settings: Examining the impact of fear of isolation, willingness to self-censor, and peer network characteristics. Mass Communication and Society, 21(1), 1-23. https://doi.org/10.1080/15205436.2017.1358819

Cornell, W. F., Graaf, A. D., Newton, T., \& Thunnissen, M. (Eds.). (2016). Into Ta: A Comprehensive Textbook on Transactional Analysis. Karnac. http://ebookcentral.proquest.com

Coşkun, H., Durak, M., \& Elgin, V. M. (2012). Kendini sansürleme isteği ölçeği: Geçerlilik ve güvenilirlik çalışması. Yeni Symposium, 50(2), 83-89. http://yenisymposium.com/Pdf/TR-YeniSempozyum-5ee71e07.PDF

Çam, S. (1999). İletişim becerileri eğitim programının öğretmen adaylarının ego durumlarına ve problem çözme becerisi. Türk Psikolojik Danışma ve Rehberlik Dergisi, 2(12), 16-27. https://dergipark.org.tr/tr/download/article-file/200150

Çelik, S. N. (2020). Çocukluk çağı travmaları, duygu düzenleme becerileri ve bilinçli farkındalık arasındaki ilişkilerin incelenmesi [Yayımlanmamış yüksek lisans tezi]. Işılk Üniversitesi.

Çetin, D. (2020). Üniversite öğrencilerinin psikolojik sağlamlıkları ile çocukluk çağı travmaları ve ototelik kişilik arasındaki ilişkilerin incelenmesi [Yayımlanmamış yüksek lisans tezi]. Dokuz Eylül Üniversitesi.

Demirkol, M. E., Uğur, K., \& Tamam, L. (2020). Çocukluk çağı travmaları ve intihar girişimleri arasındaki ilişkide psikolojik acı ve dissosiyasyonun aracı etkisi. Anadolu Psikiyatri Dergisi, 21(5), 453-460. https://doi.org/10.5455/apd.82990

Dolma, Ö. (2019). Otosansür eğilimi ölçeği'nin Türkçe versiyonu: Yapı geçerliliğine ilişkin ilk bulgular. Pamukkale Üniversitesi Sosyal Bilimler Enstitüsü Dergisi, 34, 245-257. https://doi.org/10.30794/pausbed.446145

Eker, İ., \& Yılmaz, B. (2016). Risk alma davranışı: Çocukluk çağı travmaları ve benlik saygısı temelinde bir değerlendirme. Klinik Psikiyatri Dergisi, 19(1), 27-36. https://doi.org/10.5505/kpd.2016.02996 
Ekşi, H., Bikeç, S. M., \& Ümmet, D. (2017). Öğretmen adaylarında kendini sansürleme, psikolojik kırılganlık ve koşullu öz değer. Küreselleșen Dünyada Eğitim El Kitabı (ss. 440-450). Pegem Yayıncıllk. https://doi.org/10.14527/9786053188407.28

Etchegaray, N., Scherman, A., \& Valenzuela, S. (2019). Testing the hypothesis of "impressionable years" with willingness to self-censor in chile. International Journal of Public Opinion Research, 31(2), 331-348. https://doi.org/10.1093/ijpor/edy012

Filak, V. F., Reinardy, S., \& Maksl, A. (2009). Expanding and validating applications of the willingness to self- censor scale: Self-Censorship and media advisers' comfort level with controversial topics. Journalism \& Mass Communication Quarterly, 86(2), 368-382. https://doi.org/10.1177/107769900908600207

Gündüz, A., \& Gündoğmuș, İ. (2019). Üniversite öğrencilerinde çocukluk çağı olumsuz yaşantıları ile otomatik düşünceler, ara inançlar, uyumsuz şemalar, anksiyete ve depresif belirti şiddeti ve yaşam kalitesi arasındaki ilişki. Klinik Psikiyatri Dergisi,22(4), 434-435. https://doi.org/10.5505/kpd.2019.72621

Güneri Yöyen, E. (2017). Çocukluk çağı travması ve benlik saygısı. International Journal of Social Sciences and Education Research, 3(1), 267-282. https://doi.org/10.24289/ijsser.274033

Gürbüz, S. (2019). Sosyal Bilimlerde Aracı, Düzenleyici ve Durumsal Etki Analizleri. Seçkin Yayıncilık.

Harris, T. A. (2014). Ben Ok'im - Sen Ok'sin (Çev. Ed. M. Şahin). Okuyan Us Yayıncllık.

Hayes, A. F., Glynn, C. J., \& Shananan, J. (2005a). Willingness to self-censor: A construct and measurement tool for public opinion research. International Journal of Public Opinion Research, 17(3), 298-323. https://doi.org/10.1093/ijpor/edh073

Hayes, A. F., Glynn, C. J., \& Shananan, J. (2005b). Validating the willingness to self-censor scale: Individual differences in the effect of the climate of opinion on opinion expression. International Journal of Public Opinion Research,17(4), 443-455. https://doi.org/10.1093/ijpor/edh072

Hayes, A. F., Glynn, C. J., \& Uldall, B. R. (2010). Validating the willingness to self-censor scale II: Inhibition of opinion expression in a conversational setting. Communication Methods and Measures, 4(3), 256-272. https://doi.org/10.1080/19312458.2010.505503

Hayes, A. F. (2018). Introduction to Mediation, Moderation, and Conditional Process Analysis (2nd Ed.). The Guilford Press.

İkiz, F. E. (2016). Psikolojik Danışma ve Psikoterapide Kuramlar ve Yenilikçi Yaklaşımlar. Nobel Yayıncilı.

Janssen, K., Cardoso, T. A., Fries, G. R., Branco, J. C., Silva, R. A., Kauer-Sant'Anna, M., Kapczinski, F., \& Magalhaes, P.V.S. (2016). Childhood trauma, family history, and their association with mood disorders in early adulthood. Acta Psychiatrica Scandinavica, 134(4), 281-286. https://doi.org/10.1111/acps.12551

Jenkins, L., McNeal, T., Drayer, J., \& Wang, Q. (2021). Childhood trauma history and negative social experiences in college. Journal of Child \& Adolescent Trauma, 14, 103-113. https://doi.org/10.1007/s40653-020-00315-z 
Kılıçarslan, S. (2019). Transaksiyonel analiz. Z. Karataş ve Y. Yavuzer (Eds.), Psikolojik Danışma ve Psikoterapi Kuramlarl: Örnek Uygulamalarla Temel ve Güncel Kuramlar (2. bs., ss. 377412). Pegem Akademi.

Lister-Ford, C. (2002). Skills in Transactional Analysis Counselling \& Psychotherapy. Sage Publications. https://ebookcentral.proquest.com

Matthes, J., Hayes, A. F., Rojas, H., Shen, F., Min, S. J., \& Dylko, I. B. (2012). Exemplifying a dispositional approach to cross-cultural spiral of silence research: Fear of social isolation and the inclination to self-censor. International Journal of Public Opinion Research, (24)3, 287-305. https://doi.org/10.1093/ijpor/eds015

Mitra, I. (2017). Winning Hearts and Minds: Transactional Analysis Simplified. Sage Publications. http://ebookcentral.proquest.com

Noelle-Neumann, E. (1977). Turbulences in the climate of opinion: Methodological applications of spiral of silence theory. The Public Opinion Quarterly, 41(2), 143-158. https://www.jstor.org/stable/2748333

Oflaz, F. (2015). Travma yaşamış çocuk ve gençlerin ele alınmasında çocuk-ergen ruh sağlığı ve psikiyatri hemşireliği uygulamaları. Turkiye Klinikleri Dergisi 1(2), 46-51.

Özpolat, A. R., Kaygusuz, C., \& Duyan, V. (2015). Ego durumları ölçeğinin geliştirilmesi çalışması. Turkish Journal of Family Medicine and Primary Care, 9(4), 150-157. https://doi.org/10.5455/tjfmpc.186239

Roy, R. (1998). Childhood Abuse and Chronic Pain: A Curious Relationship?. University of Toronto Press. https://ebookcentral.proquest.com

Seligman, L., \& Reichhenberg, L. W. (2019). Psikolojik Danışma ve Psikoterapi Kuramları: Sistemler, Stratejiler ve Beceriler (4. bs.) (E. E. Yerlikaya, Çev.). Pegem Akademi.

Spurgin, E. (2019). Why the duty to self-censor requires social-media users to maintain their own privacy. Res Publica, 25, 1-19. https://doi.org/10.1007/s11158-017-9378-x

Stewart, I., \& Joines, V. (2019). Günümüzde TA: Transaksiyonel Analiz'e Yeni Bir Girişs (3. bs.) (F. Akkoyun, Çev. ed.). Serbest Kitaplar.

Şamatacı, G. (2013). Romantik ilişkilerde affetme: Transaksiyonel analiz ego durumları açısından bir inceleme [Yayımlanmamış yüksek lisans tezi].Marmara Üniversitesi.

Şar, V., Öztürk, E., \& İkikardeș, E. (2012). Validity and reliability of the turkish version of the childhood trauma questionnaire (ctq). Turkiye Klinikleri Journal of Medical Sciences, 32(4), 1054-1063. https://doi.org/10.5336/medsci.2011-26947

Şar, V., Necef, I., Mutluer, T., Fatih, P., \& Türk-Kurtça, T. (2021). A revised and expanded version of the turkish childhood trauma questionnaire (ctq-33): Overprotection-overcontrol as additional factor.Journal of Trauma \& Dissociation, 22(1), 35-51. https://doi.org/10.1080/15299732.2020.1760171

Tüfekçi, S. (2008). Romantik ilişkilerde genç yetişkinlerin aşk iliş̧in tutumları ve kişilik özellikleri: Transaksiyonel analiz ego durumları açısından bir değerlendirme [Yayımlanmamış yüksek lisans tezi].Marmara Üniversitesi.

Türk Dil Kurumu Sözlükleri (2020). Güncel Türkçe sözlük. https://sozluk.gov.tr 


\section{EXTENDED ABSTRACT}

\section{Introduction}

Openly voicing ideas that others will not approve may occasionally result in social rejection, social isolation, conflict in important relationships, and physical violence (Hayes et al., 2010). The willingness to self-censorship is when the individual prefers to keep his or her ideas from the audience, who they think disagree with him (Hayes et al., 2005a). Ego states are one of the basic concepts of TA theory, which includes the interrelated thought, emotion and behavior patterns of each individual and cluster these patterns with the words Parent, Adult, and Child (Cornell et al., 2016). In the 21st century, people regularly experience traumatic events as a daily, ordinary event. These traumatic events vary considerably. Childhood physical abuse or physical neglect, emotional abuse or emotional neglect, sexual abuse are some of these (Basham \& Miehls, 2004). When childhood negative experiences become difficult to cope with, it can cause psychological and behavioral problems that can continue in adulthood and negatively affect the person's life (Janssen et al., 2016). Considering that willingness to self-censorship is a communication-oriented attitude, choice or problem, Transactional Analysis (TA) as a theory of communication that examines interpersonal communication and a psychological counseling theory with a pathological view of individuals (Stewart \& Joines, 2019) it may provide a different explanation for the willingness to self-censorship. The idea that individuals' childhood negative experiences may be related to the willingness to self-censorship in daily life and how the use of ego states can affect this situation constituted the starting point of this study. In this study, it was aimed to investigate whether there is a mediating effect of ego states in university students' childhood negative experiences and their willingness to self-censorship.

\section{Method}

In the study, the predictive correlational model (Büyüköztürk et al., 2009) based on the relational scanning model, one of the quantitative research methods, was used. The sampling model of the research is the convenient (easy) sampling model, which is one of the non-random sampling methods. The study group of the research consists of 343 university students who continue their undergraduate education in different universities and faculties. Participation in the research was provided on a voluntary basis. The Process Macro program developed by Hayes (2018) was used to test the mediating role of ego states in the relationship between childhood negative experiences and the willingness to self-censorship. Research data were obtained online by arranging the scales electronically via Google Forms.

\section{Results}

A low level of positive relationship between negative childhood experiences and the willingness to self-censorship ( $\mathrm{r}=.141, \mathrm{p}<.01)$, positive relationship between childhood negative 
experiences and child ego state $(\mathrm{r}=.324, \mathrm{p}<.01)$ A low level of significant relationship, negative childhood experiences and adult ego state $(r=-.178, p<.01)$ were found to be negatively and lowly significant.

Whether or not the negative childhood experiences of university students have an indirect effect on the willingness to self-censorship is presented according to the confidence intervals obtained with the Bootstrap technique. The mediating effect of the child ego state, an ego state included in the TA approach, was found to be significant. Accordingly, it has been determined that the indirect effect of childhood negative experiences on the willingness to self-censorship is significant, therefore, the child ego state mediates the relationship between childhood negative experiences and the willingness to self-censorship ( $b=.050,95 \%$ BCA CI $[.0283, .0756])$. The fully standardized effect size of the mediation effect is (K2) .122, and it can be said that this value is close to the medium value.

\section{Discussion \& Conclusion}

The fact that the child ego state, one of the ego states, has a mediator role in the relationship between the negative childhood experiences of university students and their willingness to self-censorship, can be interpreted as the child ego state use level increases or strengthens the predictive effect of childhood negative experiences on the willingness to selfcensorship. Childhood negative experiences may be one of the factors that increase the willingness to self-censorship. At this point, primary caregivers who are responsible for the healthy development of the individual from the prenatal period should create a role model that will help the individual to use all three ego states in a balanced way by demonstrating healthy parental attitudes, establishing effective communication and secure attachment styles with the child. In other words, it is thought that preventive studies aimed at eliminating the risk factors that may lead to negative childhood experiences, primarily by caregivers and other persons and institutions related to the child, and activating protective factors related to childhood will help the individual to use ego states in a suitable and balanced manner in his future life. Thus, it is thought that the need for the willingness to self-censorship of the communication environments of the individual, as a psychosocial entity, will decrease. In addition, psychological counselors working in the field may be recommended to conduct intervention studies such as transactional analysis theory-based group psychological counseling, psychoeducation studies, individual psychological counseling for different age groups in order to regulate the balanced use of ego states of individuals with negative childhood experiences and to raise awareness about willingness to selfcensorship behavior. 